\title{
NOTE
}

\section{Use of sandy beach habitat by Fundulus majalis, a surf-zone fish}

\author{
Chris J. Harvey* \\ Center for Limnology, University of Wisconsin, Madison, Wisconsin 53706, USA
}

\begin{abstract}
Habitat use by the striped killifish Fundulus majalis was examined at Nannygoat Beach, a sandy beach on Sapelo Island, Georgia, USA. F. majalis catch per unit effort (CPUE) was greater in runnel habitat than in any other intertidal region, and no F. majalis were captured in the low-tide surf zone. Some F. majalis occupied the same runnel on consecutive tidal cycles. F. majalis distribution may have been influenced by distributions of potential prey (surf clams Donax spp. and Mulinia spp.) and predators (blue crab Callinectes sapidus).
\end{abstract}

KEY WORDS: Habitat use - Fundulus majalis - Sandy beach Spatial heterogeneity

Like all intertidal species, sandy beach surf-zone fishes are adapted to conditions of continuous physical flux created by tides and waves. Such adaptations may be morphological, such as the flattened bodies of pleuronectid and batoid fishes, or behavioral, such as migrations into and out of the intertidal zone or preferential use of discrete habitat types (Abou-Seedo et al. 1990, Burrows et al. 1994, Gibson et al. 1996). Fishes may use such habitats for key functions such as foraging, predator avoidance, and spawning, as demonstrated in many sandy beach ecosystems (Robertson \& Lenanton 1984, Romer 1990, Ayvazian \& Hyndes 1995).

An important feature on Nannygoat Beach, a sandy beach on the southeastern shore of Sapelo Island, Georgia, USA, is the ridge-runnel systems (sensu Komar 1998). Ridges are elevated, elongated areas of sand that extend along the beach roughly parallel to the shore. Receding tides expose the ridges, and water is trapped behind them in ephemeral troughs called

\footnotetext{
·E-mail: cjharvey@students.wisc.edu
}

runnels. Runnels remain connected to the ocean at low tide by narrow drainage channels.

This study evaluated the null hypothesis that catch per unit effort (CPUE) of fishes would be equal at all tide heights and in the exposed runnel habitat, implying that fishes move in and out with the tides; alternatively, differences in CPUE would imply that particular habitats (e.g. the exposed runnel or a particular tide height) were preferred. The relationship of such habitat preference to fish size, feeding, and predator avoidance was considered. The study focused on striped killifish Fundulus majalis, a common fish in the Nannygoat Beach intertidal zone, whose habitat use patterns were more distinctive than other fishes present.

Methods. Field collections: The study took place from 19 to 24 October 1997 in the intertidal zone proximate to a large ridge-runnel system on Nannygoat Beach. The runnel, located halfway between the low tide and high tide lines (tidal amplitude $\sim 3 \mathrm{~m}$ ), was $\sim 300 \mathrm{~m}$ from end to end. Fishes were captured by beach seine $(1.5 \times 10 \mathrm{~m}, 8 \mathrm{~mm}$ stretch mesh $)$ at 3 tide heights each day (Fig 1): high tide (ridge and runnel submerged), mid tide (runnel submerged, waves breaking over the still-submerged ridge), and low tide (runnel and ridge completely exposed). Two seiners waded $25 \mathrm{~m}$ from shore, spread the seine, and moved slowly ashore perpendicular to the shoreline. Five seine hauls were made per tide level per day. The exposed runnel was seined at low tide (Fig. 1). Two seiners spread the seine and swept several cross-sections of the runnel. Volume swept was estimated from the distance across the runnel, the width of the seine, and the maximum depth seined. Fishes were identified at least to genus, and subsamples placed on ice for measurement (total length $\pm 1 \mathrm{~mm}$, weight $\pm 0.01 \mathrm{~g}$ ) and gut content analysis. 

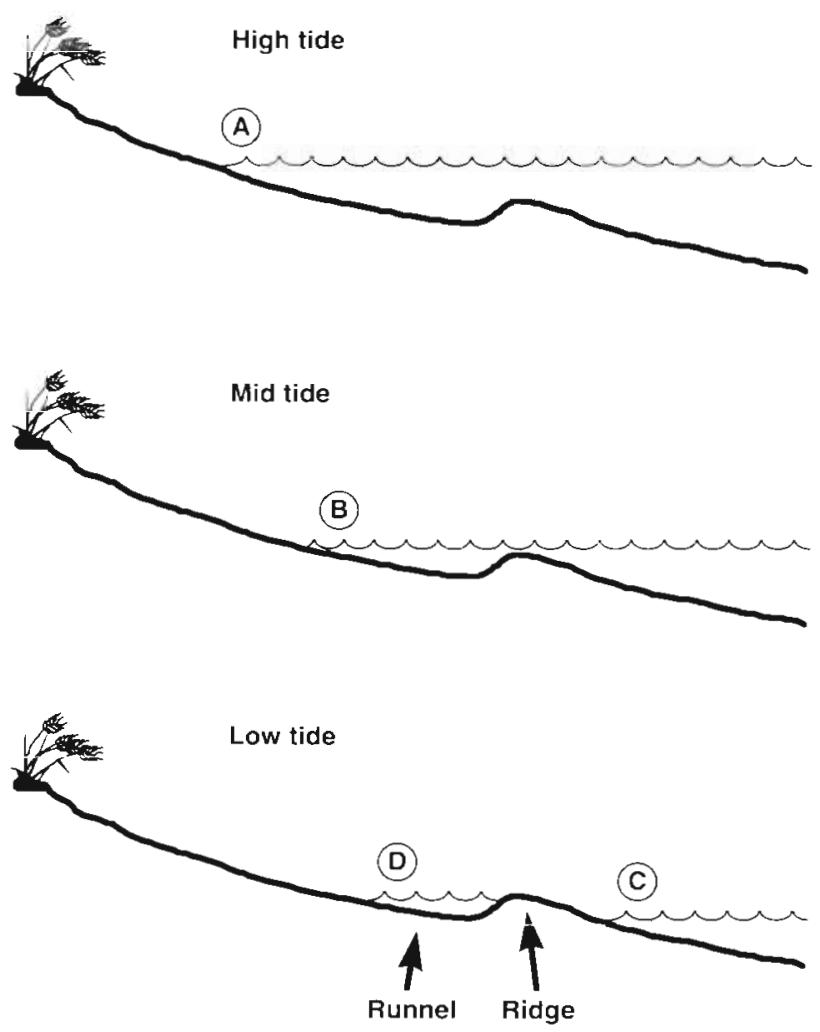

Fig. 1. Profile of sampling site (not drawn to scale). The leading $25 \mathrm{~m}$ of the surf zone was sampled at high tide (A), mid tide (B), and low tide (C). The exposed runnel was seined (D) while the tide was low

Of the 16 species captured, Fundulus majalis had the most distinctive pattern of habitat use, with especially high densities in the exposed runnel (see 'Results'). A markrecapture experiment was done on the final $2 \mathrm{~d}$ of the study to determine if individual $F$. majalis occupied the runnel on successive tidal cycles; $149 F$. majalis were marked by clipping the upper lobe of the caudal fin and released into the exposed runnel at $-12: 00 \mathrm{~h}$ on 23 October. During routine seining on 24 October, all $F$. majalis captured were carefully examined for fin clips.

Gut content analysis: Guts from $50 \mathrm{~F}$. majalis (25 high tide, 5 mid tide, 20 exposed runnel) were examined. The entire alimentary canal was removed and weighed $( \pm 0.0001 \mathrm{~g})$, the contents were removed, and the empty gut was reweighed to estimate total gut content weight. Gut contents were examined under a dissecting microscope 16 to $50 x)_{i}$ prey items were identified and their percent of total gut contents was visually estimated.
Data analysis: One-factor ANOVAs (factor = habitat $\alpha=0.05$; Bonferroni post-hoc test) were used to compare CPUE (no. per $10 \mathrm{~m}^{3}$ swept). lengths, weights, and gut content weight of Fundulus majalis in the 4 habitats (high, mid, and low tide, and exposed runnel). For CPUE comparisons, catch data from the 5 hauls at a given tide height on a given day were pooled to represent a single sample. Fish from all dates were pooled by habitat for comparison of mean lengths, somatic weights, and gut content weights to determine if habitat use was related to fish size or diet. Diet composition data were evaluated in a strictly qualitative manner.

Results. A total of 2069 fish were captured, 316 of which were Fundulus majalis, in the 4 habitats sampled. Other abundant species were Atlantic silverside Menidia menidia, gulf kingfish Menticirrhus littoralis, Florida pompano Trachinotus carolinus, and anchovies Anchoa hepsetus and A. mitchilli. Mean CPUE of $F$. majalis and other abundant fishes in each habitat is shown in Fig. 2; means are based on pooled samples from 6 high tides, 7 mid tides, 6 low tides, and 3 exposed runnel collections. CPUE of $F$. majalis was greater in the exposed runnel than in ail other habitats $\left(F_{3,18}=18.25, \mathrm{p}<0.001\right)$, and $F$. majalis was never observed at low tide. Other abundant species had different distributional patterns (Fig. 2). Habitat type influenced the CPUE of $M$. menidia $\left(F_{3.18}=3.50, \mathrm{p}=\right.$ $0.037)$ and $T$ carolinus $\left(F_{3,18}=3.35, \mathrm{p}=0.041\right)$, though post-hoc analysis yielded no pairwise differences among habitat types. $M$. littoralis CPUE was greatest at low tide $\left(F_{3.18}=5.36, \mathrm{p}=0.008\right)$. Anchoa spp. CPUE

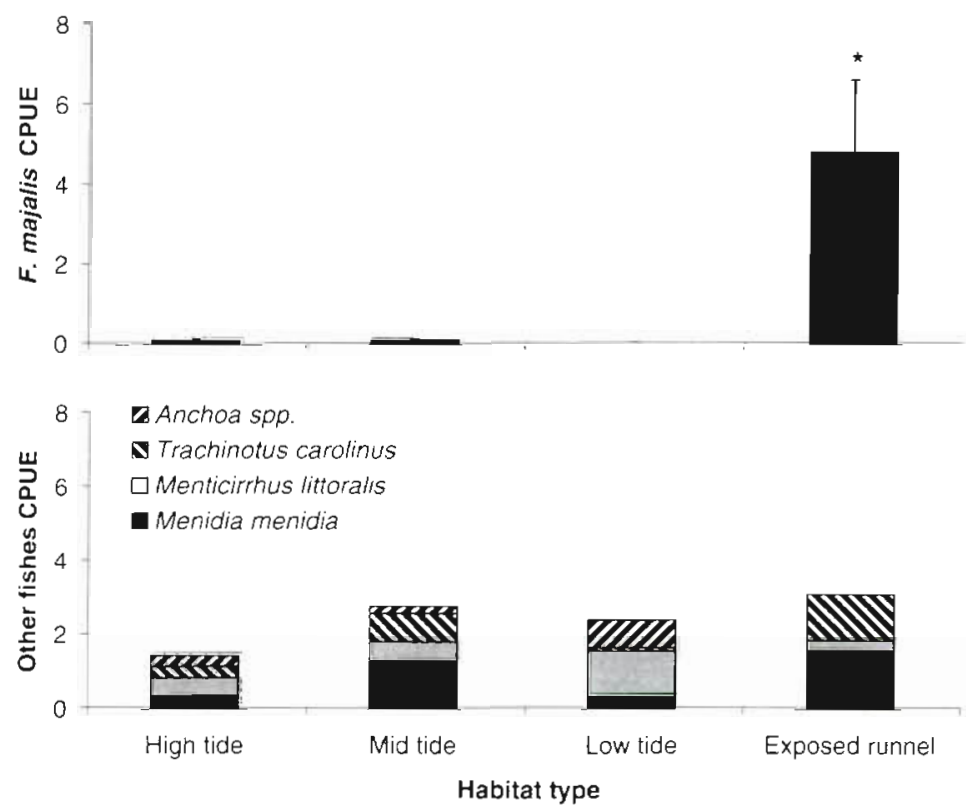

Fig. 2. Catch per unit effort (CPUE, + SE) of Fundulus majalis (top) and other abundant fishes (bottom) in 4 habitat types at Nannygoat Beach. Asterisk denotes significant difference at $\alpha=0.05$ 


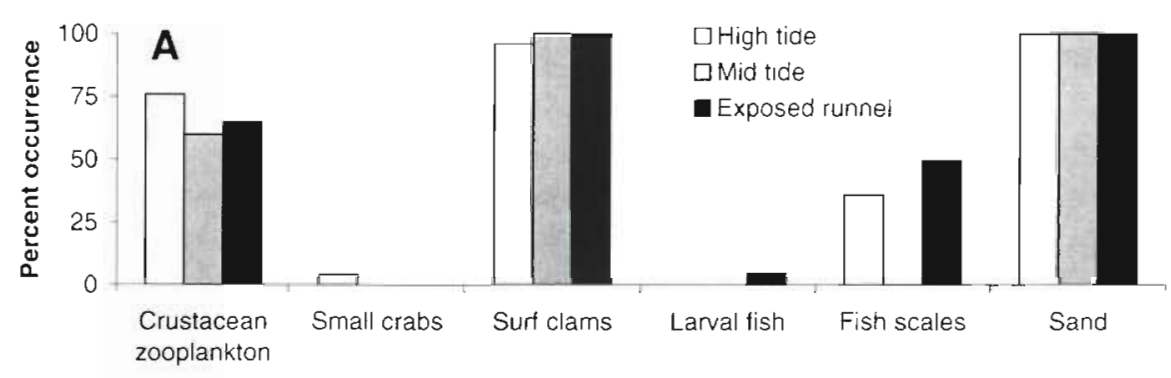

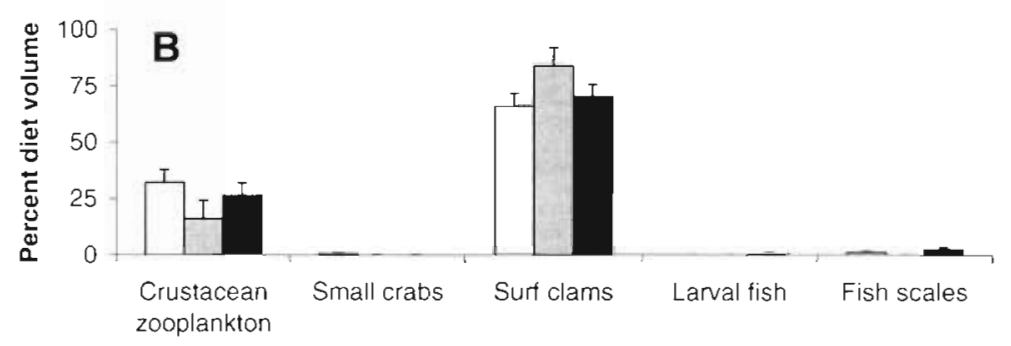

Prey type
Fig. 3. Gut content analysis of Fundulus majalis from 3 habitat types at Nannygoat Beach. (A) Frequency of occurrence of prey items. (B) Estimated \% gut content volume $(+\mathrm{SE})$ of prey items was similar at all tide heights $\left(F_{3.18}=1.24, \mathrm{p}=0.326\right)$, though they were not observed in the exposed runnel.

Of the 149 Fundulus majalis marked and released in the exposed runnel on 23 October, 11 (7.4\%) were recaptured in the exposed runnel on 24 October during routine sampling between 09:00 and 10:00 h. Ninety unmarked $F$. majalis were caught in the same sampling period. Following the routine sampling, the entire upper half of the runnel was seined, and 125 F. majalis were captured, 17 of which were marked $(13.6 \%)$.

Fundulus majalis lengths and weights were not significantly different in the 3 habitats where they occurred (length: $F_{2,133}=3.04, \mathrm{p}=0.051$; weight: $F_{2,133}$ $=2.47, \mathrm{p}=0.088$ ). The near-significance is probably related to small sample size at mid tide, where only 5 fish were measured ( $\mathrm{n}=25$ at high tide and 106 in the runnel). Mean lengths ( \pm SE) at high tide, mid tide, and exposed runnel were $72( \pm 1), 66( \pm 2)$, and $74( \pm 1) \mathrm{mm}$, respectively. Mean weights $( \pm \mathrm{SE})$ were $4.81( \pm 0.28)$, $3.64( \pm 0.38)$, and $5.15( \pm 0.16) \mathrm{g}$, respectively.

Gut content:body weight ratio and habitat were not related $\left(F_{2,47}=1.82, \mathrm{p}=0.173\right)$, nor were size (length) and gut content:body weight ratio $\left(n=50 ; r^{2}=0.00, p=\right.$ 0.89). Small $(<3 \mathrm{~mm}$ ) surf clams (Donax spp. and Mulinia spp.), crustacean zooplankton, fish scales, and sand occurred in most $F$. majalis guts regardless of habitat, although fish scales were not important at mid tide (Fig. 3A). Surf clams made up the greatest estimated volume of any prey item (Fig. 3B; the \% volume of sand was not included in this analysis, though it was typically $<5 \%$ ).

Discussion. Fundulus majalis appeared to make preferential use of the runnel habitat at Nannygoat
Beach. F. majalis was never caught at low tide, and densities in the runnel were about $45 \times$ greater than at mid or high tide. Over a tidal cycle, as the tide rises over the runnel, F. majalis inhabit the swash zone in low densities; as the tide recedes, they remain in the runnel rather than moving to the low-tide swash zone. Roughly $10 \%$ of marked $F$. majalis were recaptured in the runnel a full tidal cycle after release, which may indicate site fidelity; Lotrich (1975) found that Fundulus heteroclitus in a tidal creek exhibited a discrete home range, although Butner \& Brattstrom (1960) described similar behavior by $F$. heteroclitus as a chance event.

The distributions of other abundant species differed from Fundulus majalis. Anchoa spp. appeared to move in and out with the tide, as predicted by the null hypothesis. Menticirrhus littoralis, Trachinotus carolinus, and Menidia menidia all had non-random distributions, although none exhibited preferential use of the runnel, and only $F$. majalis displayed such a dramatic (i.e. 45-fold) difference in CPUE in a specific habitat.

Individual size was not a factor in Fundulus majalis distribution, nor were diet composition and gut content weight; however, prey availability may explain why $F$. majalis was not found at low tide. Densities of small surf clams, the most important prey for F. majalis, may not have been suitably high in low tide sediments. During this study, densities of Donax spp. and benthic amphipods at Nannygoat Beach were greatest in the upper half of the intertidal zone (T. O'Keefe, Department of Zoology, University of Wisconsin, unpubl. data). At low tide, many species of Donax remain in the saturated sand above the low tide line (Mikkelsen. 
Table 1. Callinectes sapidus. Catch per unit effort (CPUE) of blue crab in the 4 habitats sampled at Nannygoat Beach

\begin{tabular}{|lccc|}
\hline Habitat & Total volume swept $\left(\mathrm{m}^{3}\right)$ & Crab CPUE & SE \\
\hline High tide & 2600 & 0.07 & 0.05 \\
Mid tide & 1500 & 1.37 & 0.61 \\
Low tide & 2450 & 1.69 & 0.79 \\
Exposed runnel & 525 & 0.10 & 0.10 \\
\hline
\end{tabular}

1981, Leber 1982, Donn et al. 1986, but see Bonsdorff \& Nelson 1992). Thus, as the tide receded, F. majalis may have remained in the runnel, where food was still available judging from gut contents, rather than moving out into the low-tide swash zone where prey availability may have been lower.

Preuators may also have influenced Fundulus majalis distributions. During this siucly, 477 dalul female blue crabs Callinectes sapidus were captured at low and mid tide, but only 23 in the runnel and at high tide (Table 1). Many $C$. sapidus were observed exiting the runnel as the tide ebbcd. It is possible that $F$. majalis used the exposed runnel as refuge from $C$. sapidus, which preys on many intertidal fishes, including F. heteroclitus (Kneib 1982, Smith \& Weis 1997).

The fish community composition of sandy beaches varies on both a seasonal and a diel scale (Modde \& Ross 1980, Gibson et al. 1993, 1996). The scope of this study is not sufficient to describe partitioning of heterogeneous habitat by Nannygoat Beach fishes on either temporal scale. However, this study strongly implies that partitioning of habitat, in this case the runnel, occurs among the fishes of a sandy beach. Because sandy beaches serve as nursery habitat for juveniles of many pelagic fish species (Modde \& Ross 1980, Brown \& McLachlan 1990, Gibson et al. 1993), habitat heterogeneity of sandy beaches may be linked to coastal fish production.

Acknowledgements. I thank A. Pollard, D. Padilla, J. Kitchell, K. Potter, B. Greenfield, E. Bennett, T. Willis, C, Scheele, M. Schwar, and M. Schreiber for their willingness to pull the other end of the seine. J. Kitchell provided guidance and ideas throughout this project, and $\mathrm{R}$. Kneib shared useful knowledge about the nearshore fish community of Sapelo Island. The comments of $T$. Essington and 3 anonymous reviewers improved this manuscript. This study was supported in part by funds from Wisconsin Sea Grant (Girant 144FQ55, Project E/E-30-SE).

Editorial responsibility: Otto Kinne (Editor).

Oldendorf/Luhe, Germany

\section{LITERATURE CITED}

Abou-Seedo F, Clayton DA, Wright JM (1990) Tidal and turbidity effects on the shallow-water fish assemblage of Kuwait Bay (Kuwait). Mar Ecol Prog Ser 65:213-223

Ayvazian SG, Hyndes GA. (1995) Surt-zone assemblages in south-western Australia: do adjacent nearshore habitats and the warm Leeuwin Current influence the characteristics of the fish fauna? Mar Biol 122:527-536

Bonsdorff E, Nelson WG (1992) The ecology of coquina clams Donax variabilis Say, 1822, and Donax parvula Philippi, 1849 , on the east coast of Florida. Veliger 35:358-365

Brown AC, McLachlan A (1990) Ecology of sandy shores. Elsevier, Amsterdam.

Burrows MT, Gibson RN, Robb L, Comely AC (1994) Temporal patterns of movement in juvenile flatfishes and their predators: underwater television observations. J Exp Mar Biol Ecol 177:251-268

Butner A, Brattstrom BH (1960) Local movement in Menidia and Fundulus. Copeia 1960:139-141

Donn TE Jr, Clarke DJ, McLachlan A, du Toit P (1986) Distribution and abundance of Donax serra Röding (Bivalvia: Dundadae) as related to beach morphology. I. Semilunar migrations. J Exp Mar Biol Ecol 102:121-131

Gibson RN, Ansell AD, Robb L (1993) Seasonal and annual variations in abundance and species composition of fish and macrocrustacean communities on a Scottish sandy beach. Mar Ecol Prog Ser 98:83-105

Gibson RN, Robb L, Burrows MT, Ansell AD (1996) Tid.al, diel and longer term changes in the distribution of fishes on a Scottish sandy beach. Mar Ecol Prog Ser 130:1-17

Kneib RT (1982) The effects of predation by wading birds (Ardeidae) and blue crabs (Callinectes sapidus) on the population size structure of the common mummichog. Fundulus heteroclitus. Estuar Coast Shelf Sci 14:159-166

Komar PD (1998) Beach processes and sedimentation. Prentice Hall, Upper Saddle River, NJ

Leber KM (1982) Bivalves (Tellinacea: Donacidae) on a North Carolina, USA, beach: contrasting population size structures and tidal migrations. Mar Ecol Prog Ser 7:297-302

Lotrich VA (1975) Summer home range and movements of Fundulus heteroclitus (Pisces: Cyprinodontidae) in a tidal creek. Ecology 56:191-198

Mikkelsen PS (1981) A comparison of 2 Florida, USA, populations of the coquina clam, Donax variabilis (Bivalvia: Donacidae): 1. Intertidal density, distribution and migration. Veliger 23:230-239

Modde T, Ross ST (1980) Seasonality of fishes occupying a surf zone habitat in the northern Gulf of Mexico. Fish Bull 78:911-922

Robertson AI, Lenanton RCJ (1984) Fish community structure and food chain dynamics in the surf-zone of sandy beaches: the role of detached macrophyte detritus. J Exp Mar Biol Ecol 84:265-283

Romer GS (1990) Surf zone fish community and species response to a wave energy gradient. J Fish Biol 36: 279-287

Smith GM, Weis JS (1997) Predator-prey relationships in mummichogs (Fundulus heteroclitus (L.)): effects of living in a polluted environment. J Exp Mar Biol Ecol 209:75-87

Submitted: January 8, 1998; Accepted: February 16, 1998

Proofs received from author(s): March 18, 1998 